\title{
Differential effects of extreme drought on production and respiration: synthesis and modeling analysis
}

\author{
Z. Shi ${ }^{1}$, M. L. Thomey ${ }^{2}$, W. Mowll ${ }^{3}$, M. Litvak ${ }^{2}$, N. A. Brunsell ${ }^{4}$, S. L. Collins ${ }^{2}$, W. T. Pockman ${ }^{2}$, M. D. Smith ${ }^{3}$, \\ A. K. Knapp ${ }^{3}$, and Y. Luo ${ }^{1}$ \\ ${ }^{1}$ Department of Microbiology and Plant Biology, University of Oklahoma, OK, USA \\ ${ }^{2}$ Department of Biology, MSC03-2020, University of New Mexico, Albuquerque, NM 87131, USA \\ ${ }^{3}$ Department of Biology and Graduate Degree Program in Ecology, Colorado State University, Fort Collins, CO 80523, USA \\ ${ }^{4}$ Department of Geography, University of Kansas, Lawrence, KS 66045, USA
}

Correspondence to: Z. Shi (zheng.shi-1@ou.edu)

Received: 17 September 2013 - Published in Biogeosciences Discuss.: 18 October 2013

Revised: 23 December 2013 - Accepted: 3 January 2014 - Published: 4 February 2014

\begin{abstract}
Extremes in climate may severely impact ecosystem structure and function, with both the magnitude and rate of response differing among ecosystem types and processes. We conducted a modeling analysis of the effects of extreme drought on two key ecosystem processes, production and respiration, and, to provide a broader context, we complemented this with a synthesis of published results that cover a wide variety of ecosystems. The synthesis indicated that across a broad range of biomes, gross primary production (GPP) was generally more sensitive to extreme drought (defined as proportional reduction relative to average rainfall periods) than was ecosystem respiration (ER). Furthermore, this differential sensitivity between production and respiration increased as drought severity increased; it occurred only in grassland ecosystems, and not in evergreen needle-leaf and broad-leaf forests or woody savannahs. The modeling analysis was designed to enable a better understanding of the mechanisms underlying this pattern, and focused on four grassland sites arrayed across the Great Plains, USA. Model results consistently showed that net primary productivity (NPP) was reduced more than heterotrophic respiration $\left(R_{\mathrm{h}}\right)$ by extreme drought (i.e., $67 \%$ reduction in annual ambient rainfall) at all four study sites. The sensitivity of NPP to drought was directly attributable to rainfall amount, whereas the sensitivity of $R_{\mathrm{h}}$ to drought was driven by soil drying, reduced carbon (C) input and a drought-induced reduction in soil C content a much slower process. However, differences in reductions in NPP and $R_{\mathrm{h}}$ diminished as extreme drought continued, due to a gradual decline in the soil $\mathrm{C}$ pool leading to further re-
\end{abstract}

ductions in $R_{\mathrm{h}}$. We also varied the way in which drought was imposed in the modeling analysis; it was either imposed by simulating reductions in rainfall event size (ESR) or by reducing rainfall event number (REN). Modeled NPP and $R_{\mathrm{h}}$ decreased more by ESR than REN at the two relatively mesic sites but less so at the two xeric sites. Our findings suggest that responses of production and respiration differ in magnitude, occur on different timescales, and are affected by different mechanisms under extreme, prolonged drought.

\section{Introduction}

The hydrological cycle is forecast to be intensified by climate warming, leading to increased drought frequency and severity, especially in water-limited ecosystems (IPCC, 2007). Responses of ecosystem processes to drought, especially carbon (C) fluxes, are critical, given that any net change of ecosystem $\mathrm{C}$ balance acts as a feedback to climate change. Many studies have reported ecosystem responses to climate extremes. For example, Ciais et al. (2005) reported that heat and severe drought caused an unprecedented continental scale reduction in primary productivity with ecosystem respiration decreasing concurrently. By contrast, by analyzing observational data from a global network of eddy flux towers, Schwarm et al. (2010a) found that global mean gross primary production (GPP) was more sensitive to a drought event than respiration. In a long-term field experiment, Jentsch et al. (2011) imposed an extreme drought in a constructed 
grassland and reported the opposite - that drought decreased soil respiration without reducing net primary production (NPP). Finally, by decreasing throughfall in a Mediterranean evergreen forest, Mission et al. (2010) reported a greater reduction in GPP than that in ecosystem respiration (ER), especially soil respiration. Such divergent responses of ecosystem productivity and respiration to extreme drought suggests that greater mechanistic understanding is needed with regard to how these two key $\mathrm{C}$ cycling processes are likely to respond to climate extremes.

Drought can affect production and respiration through both common and unique mechanisms. Drought lowers plant $\mathrm{C}$ uptake by reducing stomatal conductance and leaf area, and by increasing soil water deficit (Bréda et al., 2006), whereas soil water deficits and reduced substrate availability can reduce ecosystem respiration (Luo and Zhou, 2006). Although there are now many studies that have reported $\mathrm{C}$ cycling responses to both natural and experimentally imposed droughts in a variety of biomes (e.g., Reichstein et al., 2002; Ciais et al., 2005; Schwalm et al., 2012), these have not been synthesized to determine if there are any general patterns of production and respiration responses to extreme drought across terrestrial biomes (but see Schwalm et al., 2010a). Identifying such patterns is key in determining whether general mechanisms underlie production and respiration responses.

One critical limitation to both observational and experimental studies is that they are all conducted on short time scales - from seasonal to annual in length - whereas ecological responses to drought over the longer term are likely to be more complex (Anderson et al., 2011). This is especially true for heterotrophic respiration, which is affected by droughtinduced reductions in the soil $\mathrm{C}$ pool as a function of lower GPP (Mission et al., 2010). Knowing how ecosystems respond to long-term, extreme drought is important given that climate models predict an increase in the frequency and magnitude of these events in the future (Dai, 2011). It has been hypothesized that although the sensitivity of production and respiration to drought may differ initially, they will eventually become equivalent as carbon cycle processes equilibrate over time (Luo and Weng, 2011). Such long-term response patterns of ecosystems to drought are difficult to reveal in experiments or observational studies but can be explored by ecosystem modeling (Luo et al., 2011).

Drought has often been imposed in global change experiments by reducing each rainfall event amount (Yahdjian and Sala, 2006, Mission et al., 2010, Cherwin and Knapp, 2012). However, as climate models have predicted decreases in rainfall frequency in the future, drought could also occur due to declines in rainfall event number (e.g., Báez et al., 2013). These two different types of drought may affect ecosystem functions differently. For example, Harper et al. (2005) observed more drought-induced reduction on aboveground NPP (ANPP) and soil $\mathrm{CO}_{2}$ flux under natural drought caused by reducing rainfall event number and size than by simply altering the size of each rainfall event. This drought-event size interaction has also been observed in shortgrass steppe where experimental droughts only reduced ANPP when rainfall events were frequent and small rather than few but large (Cherwin and Knapp, 2012).

Our objectives were twofold. First, we determined if general patterns of drought effects on production and respiration exist across multiple biomes based on published papers on both observational and experimental studies. Second, we used an ecosystem model to examine mechanisms that possibly underly the differential sensitivity of production and respiration in four different grassland types over a rainfall gradient in the Great Plains in the central US. In the modeling analysis, we assessed responses of NPP and heterotrophic respiration $\left(R_{\mathrm{h}}\right)$ to a long-term severe drought imposed by either reducing the size or the number of individual rainfall events. In addition to assessing responses over longer time scales and mechanistically, we also compared responses in these sites using identical treatments, thus overcoming a weakness of syntheses of published studies that each impose drought in different ways and with different magnitudes, and that each measure responses a unique way (Luo et al. 2011).

\section{Materials and methods}

\subsection{Synthesis methods and data analysis}

We searched the ISI web of science using these search strings: "(drought OR severe drought OR extreme drought) AND (ecosystem fluxes OR ecosystem carbon balance)", "drought AND net ecosystem $\mathrm{CO}_{2}$ exchange (NEE) AND eddy covariance", "(precipitation OR drought OR rainfall) AND net ecosystem exchange AND manipulation" and "drought AND NPP AND respiration" in order to identify both observational and manipulative studies of drought effects on ecosystem $\mathrm{C}$ fluxes over global terrestrial biomes. We also used 'rain forest AND eddy flux AND drought' to search for studies focused more appropriately on seasonal droughts in rain forest dry seasons. We reviewed the most relevant studies in which GPP and ER were reported in both drought and normal years or dry and wet seasons for rainforest (Table 3 and Table S1).

Drought was categorized as extreme drought when ecosystems experienced more than a $40 \%$ decrease in annual precipitation relative to the long-term average, as moderate drought with less than a $40 \%$ but more than a $25 \%$ rainfall decrease, and as minor drought with less than $25 \%$ precipitation reduction. The drought sensitivity of production as estimated by GPP and respiration estimated by ER for each study site was calculated as the drought induced absolute reduction relative to the normal year divided by GPP or ER in the normal years (i.e., $\Delta \mathrm{GPP} \%=\left(\mathrm{GPP}_{\text {normal }}-\mathrm{GPP}_{\text {drought }}\right) / \mathrm{GPP}_{\text {normal }}$ or $\left.\Delta \mathrm{ER} \%=\left(\mathrm{ER}_{\text {normal }}-\mathrm{ER}_{\text {drought }}\right) / \mathrm{ER}_{\text {normal }}\right)$. The differential 
sensitivities were also assessed based on ecosystem types. The ecosystems were divided into grassland, evergreen needle-leaf forest (ENF), broad-leaf forest (BF) and woody savannahs (WS). One open shrubland, one oak woodland and one pine woodland were not included in the data analysis due to limited sample size. The significance between $\triangle$ GPP $\%$ and $\Delta \mathrm{ER} \%$ was tested using paired-sample $t$ test. Seasonal drought effects on $\triangle \mathrm{GPP} \%$ and $\triangle \mathrm{ER} \%$ in rainforest were not included in this analysis because of different responses and underlying mechanisms. Thus, seasonal drought effects in rainforest are discussed separately in this study.

\subsection{Modeling analyses}

\subsubsection{Model description}

The terrestrial ecosystem model (TECO) is a process-based ecosystem model and was designed in order to examine ecosystem responses to climatic perturbations including elevated $\mathrm{CO}_{2}$, warming and altered precipitation (Luo et al., 2008; Weng and Luo, 2008). The algorithms applied in TECO are described in detail by Weng and Luo (2008). Here we provide a brief description, focusing on mechanisms related to drought.

TECO is composed of four major submodels that represent canopy processes, plant growth, $\mathrm{C}$ transfer, and soil water dynamics. The canopy photosynthesis-transpiration submodel is a two-leaf model with multiple canopy layers, derived primarily from Wang and Leuning (1998), to simulate canopy energy balance, canopy photosynthesis and conductance. At each layer, foliage is divided into sunlit and shaded leaves. Leaf photosynthesis and transpiration are estimated by coupling the Farquhar photosynthesis (Farquhar et al., 1980) and Ball-Berry stomata-conductance model (Ball et al., 1987). In the plant growth submodel, allocation of photosynthetic assimilates depends on growth rate of leaves, stems and roots following the ALFALFA model (Denison and Loomis, 1989), and varies with phenology following Canadian Terrestrial Ecosystem Model (CTEM) (Arora and Boer, 2005). Phenology is represented by seasonal variation in leaf area index (LAI). Leaf onset is determined by growing degree days and leaf senescence is induced by low temperature and low soil water content. The $\mathrm{C}$ transfer submodel simulates movement of $\mathrm{C}$ from plant to soil $\mathrm{C}$ pools in three layers through litterfall and the decomposition of litter and soil organic C. Carbon fluxes from litter and soil carbon pools are based on residence time of each $\mathrm{C}$ pool and the $\mathrm{C}$ pool sizes (Luo and Reynolds, 1999).

The soil water dynamics submodel has ten soil layers and simulates the dynamics of soil water content based on precipitation, evaporation, transpiration, and runoff. Evaporation is determined by water content of the first soil layer and the evaporative demand of the atmosphere. Transpiration is regulated by stomatal conductance and the soil water content of layers where roots are present. When precipita- tion exceeds water recharge to soil water holding capacity, runoff occurs. In this study, a soil moisture scalar, $\omega$, is the most important parameter because the reduction in precipitation directly affects soil water content and thus the soil moisture scalar. In TECO, relative soil water content is defined as $\omega=\left(W_{\text {soil }}-W_{\min }\right) /\left(W_{\max }-W_{\min }\right)$ where $W_{\max }$ is soil water holding capacity, $W_{\min }$ is the permanent wilting point and $W_{\text {soil }}$ is soil water content. Photosynthesis and plant growth rate are reduced whenever $\omega$ is less than 0.3 .

\subsubsection{Study sites}

The sites selected for the modeling analysis are the Konza Prairie Biological Station (Konza), the Hays Agricultural Research Center (Hays), the High Plains Grasslands Research Center (Cheyenne), and the Sevilleta National Wildlife Refuge (Sevilleta). The four grasslands are distributed along mean annual temperature (MAT) and mean annual precipitation (MAP) gradients (Table 1). Cheyenne has the lowest mean annual temperature among the four sites (Table 1). Sevilleta has much coarser soil texture than the other three grasslands.

\subsubsection{Modeling scenarios}

The objective of this experimental simulation was to use the long-term records of rainfall to model extreme drought effects on ecosystem $\mathrm{C}$ dynamics. Therefore, the long-term records of daily rainfall data were collected from the weather stations closest to each grassland. The periods of rainfall data were 1982-2010 for Konza, 1949-2010 for Hays and Sevilleta, and 1949-2011 for Cheyenne. The four meteorological variables (solar radiation, air temperature, soil temperature, and relative humidity) used to drive the model were from 2007 for Konza, Cheyenne, and Sevilleta, and from 2006 for Hays, and the four meteorological variables were repeated for each rainfall year. In order to simulate the effects of extreme drought, the annual rainfall amount was reduced to $33 \%$ of ambient rainfall by two approaches. One was to reduce each rainfall event size (ESR) by $67 \%$ of ambient rainfall (AMB), and the other was to reduce rainfall event number (REN) to achieve the same reduction $(67 \%)$ in annual rainfall as for ESR. The REN treatment resulted in intermittent periods with no rain events and thus increased precipitation variability compared with ESR treatment. These two treatments allowed us to explore the differential effects of drought and increased rainfall variability on ecosystem $\mathrm{C}$ dynamics in different grassland ecosystems along the MAT and MAP gradients. The selection of $67 \%$ rainfall reduction in the model was based on analysis of long-term rainfall records in central US grasslands. Multiyear drought similar to $67 \%$ rainfall reduction occurred, but only 4-6 times in a $70 \mathrm{yr}$ record for semiarid Colorado and a $108 \mathrm{yr}$ record for mesic Kansas (data not shown). 
Table 1. Key climate, plant, and soil characteristics of four grassland ecosystem types located within the Great Plains, USA.

\begin{tabular}{lllll}
\hline & Konza & Hays & Cheyenne & Sevilleta \\
\hline Latitude & $39^{\circ} 05^{\prime} \mathrm{N}$ & $38^{\circ} 53^{\prime} \mathrm{N}$ & $41^{\circ} 11^{\prime} \mathrm{N}$ & $34^{\circ} 20^{\prime} \mathrm{N}$ \\
Longitude & $96^{\circ} 35^{\prime} \mathrm{W}$ & $99^{\circ} 23^{\prime} \mathrm{W}$ & $104^{\circ} 54^{\prime} \mathrm{W}$ & $106^{\circ} 43^{\prime} \mathrm{W}$ \\
Grassland & Tallgrass & Southern & Northern & Desert/ \\
Type & & mixed-grass & mixed-grass & shortgrass \\
MAT $\left({ }^{\circ} \mathrm{C}\right)$ & 12.9 & 12.0 & 7.6 & 13.3 \\
MAP $(\mathrm{mm})$ & 860 & 577 & 384 & 242 \\
Soil texture & Silty clay & Silty clay & fine- & Sandy \\
& loam & loam & & loamy \\
\end{tabular}

${ }^{1}$ Heislter-White et al. (2009); ${ }^{2}$ Carrillo et al. (2011); ${ }^{3}$ Muldavin et al. (2008).

\subsubsection{Statistical analysis}

The linear regressions were conducted with SigmaPlot version 12. A Student's $t$ test for the slope difference between ambient condition and rainfall reduction treatments was conducted with SAS software (SAS Institute Inc., Cary, NC, USA). A multiple regression between relative reduction in $R_{\mathrm{h}}$ (dependent variable) and the relative reduction in soil water content (SWC), NPP, and soil C content (independent variables) was performed to assess the relative contribution to drought-induced reduction in $R_{\mathrm{h}}$ by each of the three factors. The regression model is $\Delta R_{\mathrm{h}}=a \times \Delta \mathrm{SWC}+b \times$ $\Delta \mathrm{NPP}+c \times \Delta$ Soil $\mathrm{C}+\varepsilon$. The relative contributions are calculated as $a \times \Delta \mathrm{SWC} / \Delta R_{\mathrm{h}} \times 100 \%, b \times \Delta \mathrm{NPP} / \Delta R_{\mathrm{h}} \times 100 \%$ and $c \times \Delta$ Soil C $/ \Delta R_{\mathrm{h}} \times 100 \%$.

\section{Results}

\subsection{Model validation}

The TECO model was driven by meteorological data from eddy flux towers for Konza tallgrass prairie and Sevilleta desert grassland and from meteorological stations for the Hays and Cheyenne mixed-grass prairie sites. Meteorological data include hourly solar radiation, air temperature, soil temperature, precipitation and relative humidity from 20072010. For Hays, meteorological data from 2006 instead of 2007 were used, due to an incomplete record for 2007. The model was validated against the daily net ecosystem $\mathrm{CO}_{2} \mathrm{ex}$ change (NEE) from eddy flux towers during 2007-2010 at Konza and Sevilleta (Fig. 1), along with biometric data including ANPP and soil respiration measured at these grasslands (Table 2). For all the variables, the modeled results were in good agreement with observational data (Fig. 1 and Table 2).

\subsection{Differential drought effects on production and respiration and mechanisms: literature synthesis}

We synthesized results from 39 studies that included grasslands, deciduous broad-leaf forests, evergreen needle-leaf
Table 2. Comparisons between modeled and measured aboveground net primary production (ANPP) and soil respiration $\left(R_{\mathrm{S}}\right)$.

\begin{tabular}{llllcc}
\hline & \multicolumn{2}{c}{ ANPP $\left(\mathrm{g} \mathrm{m}^{-2}\right)$} & & \multicolumn{2}{c}{ Monsoon $R_{\mathrm{S}}{ }^{*}\left(\mathrm{~g} \mathrm{C} \mathrm{m}^{-2}\right)$} \\
\cline { 2 - 3 } \cline { 5 - 6 } & Observed & Modeled & & Observed & Modeled \\
\hline Konza & $461(134)^{\mathrm{a}}$ & $488(38)$ & & - & - \\
Hays & $300(-)^{\mathrm{b}}$ & $342(46)$ & & - & - \\
Cheyenne & $130(25)^{\mathrm{c}}$ & $163(15)$ & & - & - \\
Sevilleta & $140(3)^{\mathrm{d}}$ & $165(2)$ & & $63(3)^{\mathrm{e}}$ & $81(8)$ \\
\hline
\end{tabular}

${ }^{a}$ mean ANPP from 1984-1998 (Knapp et al., 2006); ${ }^{b}$ Long-term mean ANPP

(Heisler-White et al., 2009); ${ }^{\mathrm{c}}$ PHACE measurement (personal communication); ${ }^{\mathrm{d}}$ average in 2007 and 2008 (Thomey et al., 2011); ${ }^{\text {e }}$ average in 2007 and 2008 (Vargas et al., 2012). Values in the parentheses are standard errors across years. "-" means that values were not available. "monsoon $R_{\mathrm{S}}{ }^{*}$ " is the cumulative soil respiration during monsoon season from July through September in the Sevilleta desert grassland.

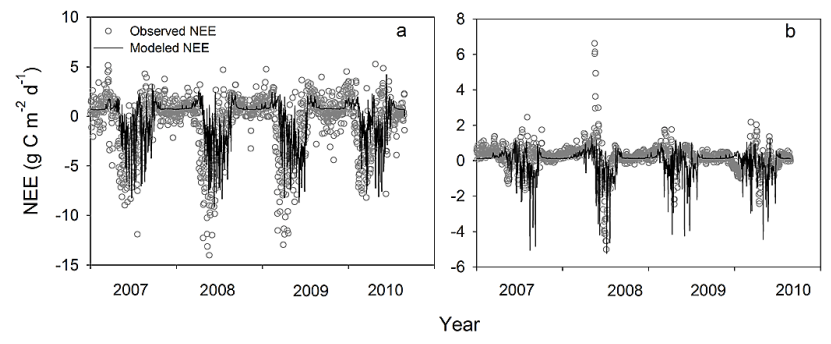

Fig. 1. Comparisons between observed daily NEE from eddy flux data and modeled daily NEE in the Konza tallgrass prairie (a) and the Sevilleta desert grassland (b) from 2007 to 2010. Overall, the TECO model can reproduce observed NEE.

forests, woody savanna and shrubland (Table S1). Eleven out of the 39 study sites experienced extreme drought (i.e., $>40 \%$ below long-term average rainfall), 10 sites experienced moderate drought, and 18 sites were subject to minor drought. GPP was more sensitive to drought than ER under extreme and moderate drought (Fig. 2a). Minor drought had no differential impacts on GPP or ER. Drought had greater impact on GPP than ER in grassland ecosystems, whereas in forest and woody savannah ecosystem, drought did not have differential impact (Fig. 2b).

For the five study sites with available data, seasonal drought in rainforest had only a limited impact on GPP (Table 3), likely because the tree-root systems had access to an adequate water supply in deep soil layers. Respiration, especially heterotrophic respiration, was reduced due to drying of the surface soil. As a consequence, ecosystem carbon uptake actually increased under seasonal drought in tropical rainforests.

\subsection{Modeled drought effect on ecosystem $C$ variables}

Both extreme drought treatments decreased annual NPP, heterotrophic respiration $\left(R_{\mathrm{h}}\right)$, NEE and soil C content, with similar patterns over modeled years in each of the four grasslands (Figs. 3 and S1). The relative reduction in NPP was 
Table 3. Synthesis of published studies on the differential responses of GPP and ER to extreme seasonal drought in tropical rainforest.

\begin{tabular}{|c|c|c|c|c|c|}
\hline Site & Biome type & Results & Mechanisms & Reference & Note \\
\hline $\begin{array}{l}\text { Tapajos km83, } \\
\text { Brazil }\end{array}$ & $\begin{array}{l}\text { Amazonian } \\
\text { rain forest }\end{array}$ & $\begin{array}{l}\text { Seasonal drought did not impact } \\
\text { GPP, but decreased ER }\end{array}$ & $\begin{array}{l}\text { Deep rooting depth buffered } \\
\text { drought stress on GPP }\end{array}$ & $\begin{array}{l}\text { Saleska et al. (2003); } \\
\text { Goulden et al. (2004) }\end{array}$ & $\begin{array}{l}\text { Eddy } \\
\text { flux }\end{array}$ \\
\hline $\begin{array}{l}\text { Tapajos km67, } \\
\text { Brazil }\end{array}$ & $\begin{array}{l}\text { Amazonian } \\
\text { rain forest }\end{array}$ & $\begin{array}{l}\text { Seasonal drought reduced GPP } \\
\text { less than ER }\end{array}$ & $\begin{array}{l}\text { Adequate water supply for photo- } \\
\text { synthesis during dry season }\end{array}$ & Hutyra et al. (2007) & $\begin{array}{l}\text { Eddy } \\
\text { flux }\end{array}$ \\
\hline $\begin{array}{l}\text { French Guiana, } \\
\text { South America }\end{array}$ & $\begin{array}{l}\text { Neotropical } \\
\text { rainforest }\end{array}$ & $\begin{array}{l}\text { Seasonal drought increased GPP, } \\
\text { but reduced ER }\end{array}$ & $\begin{array}{l}\text { Drought-associated higher inci- } \\
\text { dent radiation increased GPP }\end{array}$ & Bonal et al. (2008) & $\begin{array}{l}\text { Eddy } \\
\text { flux }\end{array}$ \\
\hline $\begin{array}{l}\text { Sardinilla, } \\
\text { Panama }\end{array}$ & Plantation & $\begin{array}{l}\text { Seasonal drought reduced both } \\
\text { GPP and ER by a similar amount }\end{array}$ & $\begin{array}{l}\text { Deep rooting depth buffered } \\
\text { drought stress on GPP }\end{array}$ & Wolf et al. (2011) & $\begin{array}{l}\text { Eddy } \\
\text { flux }\end{array}$ \\
\hline $\begin{array}{l}\text { Xishuangbanna, } \\
\text { China }\end{array}$ & $\begin{array}{l}\text { Tropical } \\
\text { rain forest }\end{array}$ & $\begin{array}{l}\text { Seasonal drought reduced less on } \\
\text { GPP than on ER }\end{array}$ & $\begin{array}{l}\text { Deep rooting depth alleviated } \\
\text { drought stress on GPP }\end{array}$ & Zhang et al. (2010) & $\begin{array}{l}\text { Eddy } \\
\text { flux }\end{array}$ \\
\hline
\end{tabular}

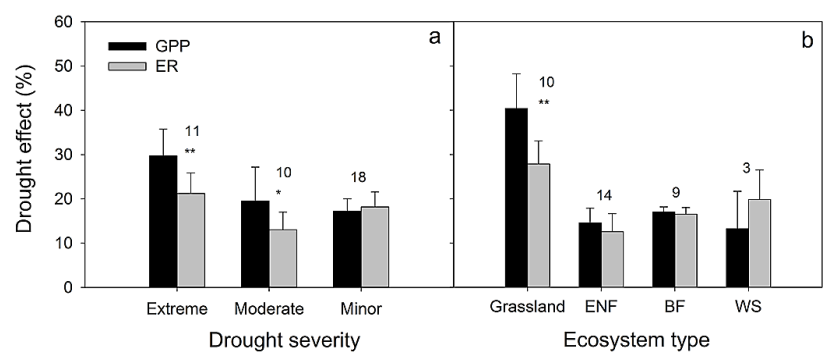

Fig. 2. Synthesized published observational and experimental results on sensitivity of gross primary production (GPP) and ecosystem respiration (ER) to drought severity (a) and to drought in different ecosystem types (b). The ecosystems were divided into grassland, evergreen needle-leaf forest (ENF), broad-leaf forest (BF) and woody savannahs (WS). One open shrubland, one oak woodland and one pine woodland were not included in the data analysis due to limited sample size. Numbers represent the number of studies included, ${ }^{* *}$ represents significant $(P<0.05)$ difference and ${ }^{*}$ represents marginally significant difference $(P<0.1)$.

consistently greater than in $R_{\mathrm{h}}$ in all the grassland sites, but the difference diminished over time due to continued decreases in $R_{\mathrm{h}}$ with drought (Fig. 3a-h). Annual GPP and ER showed similar drought responses to annual NPP and $R_{\mathrm{h}}$, respectively (Fig. S2). However, in order to reveal directional change in $R_{\mathrm{h}}$, we used annual NPP and $R_{\mathrm{h}}$ in the model analysis. The differential responses of NPP and $R_{\mathrm{h}}$ to drought caused $\mathrm{NEE}$ to increase (more ecosystem $\mathrm{CO}_{2}$ release), but the drought-induced change in NEE decreased over time (Fig. 3i-1). Drought-induced reduction in soil $\mathrm{C}$ content also increased over time, and $R_{\mathrm{h}}$ remained the same in all the study sites (Fig. 3m-p).

Annual NPP, $R_{\mathrm{h}}$, NEE and soil C content responded differently to the two different drought types (Figs. S1 and 3 and Table S2). In the tallgrass prairie and the Hays mixed-grass prairie, annual NPP, $R_{\mathrm{h}}$, and soil C content decreased more under ESR than under REN, whereas annual NPP, $R_{\mathrm{h}}$, and soil $\mathrm{C}$ content decreased less under ESR than under REN

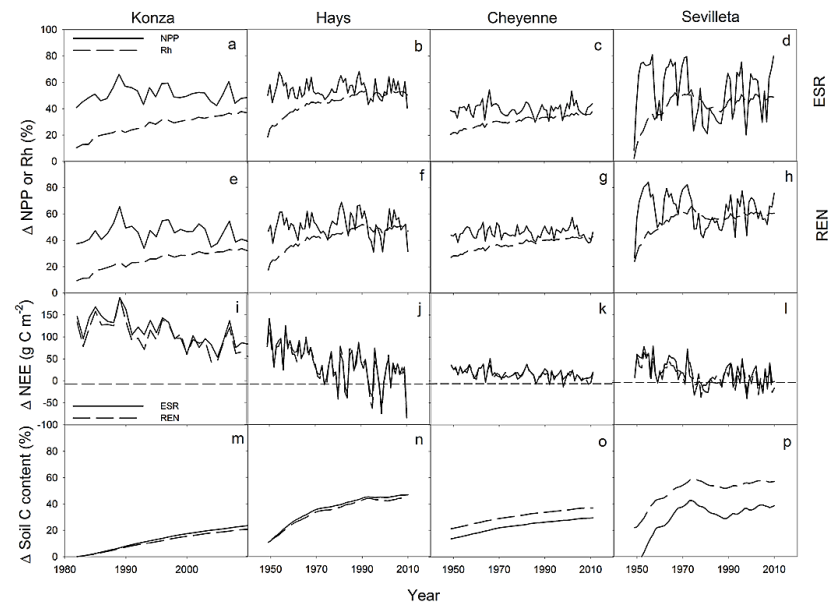

Fig. 3. Drought-induced reductions in modeled annual NPP, $R_{\mathrm{h}}$, $\mathrm{NEE}$ and soil $\mathrm{C}$ content over time in four North American grasslands (Konza: a, e, i and m; Hays: b, f, j and $\mathbf{n}$; Cheyenne: $\mathbf{c}, \mathbf{g}$, $\mathbf{k}$ and $\mathbf{o}$; Sevilleta: $\mathbf{d}, \mathbf{h}, \mathbf{l}$ and $\mathbf{p}$ ). Absolute reduction in NEE was calculated as the difference in NEE between drought treatments and ambient condition. Relative reduction in NPP, $R_{\mathrm{h}}$ and soil C content were presented and calculated as absolute reduction divided by ambient condition. Differential effects of long-term droughts diminish over time as soil $\mathrm{C}$ content decreases.

in the Cheyenne mixed-grass prairie and the desert grassland (Sevilleta). Differential responses of NEE to the two drought types were contingent upon year. Overall, Sevilleta had the greatest interannual variability $(23,19$, and $29 \%$ average coefficient of variation over the two rainfall treatments) whereas the mixed grass site near Cheyenne had the lowest interannual variability $(10,12$, and $17 \%$ average coefficient of variation over the two rainfall treatments for relative reductions in NPP, $R_{\mathrm{h}}$, and soil C, respectively) with drought. 


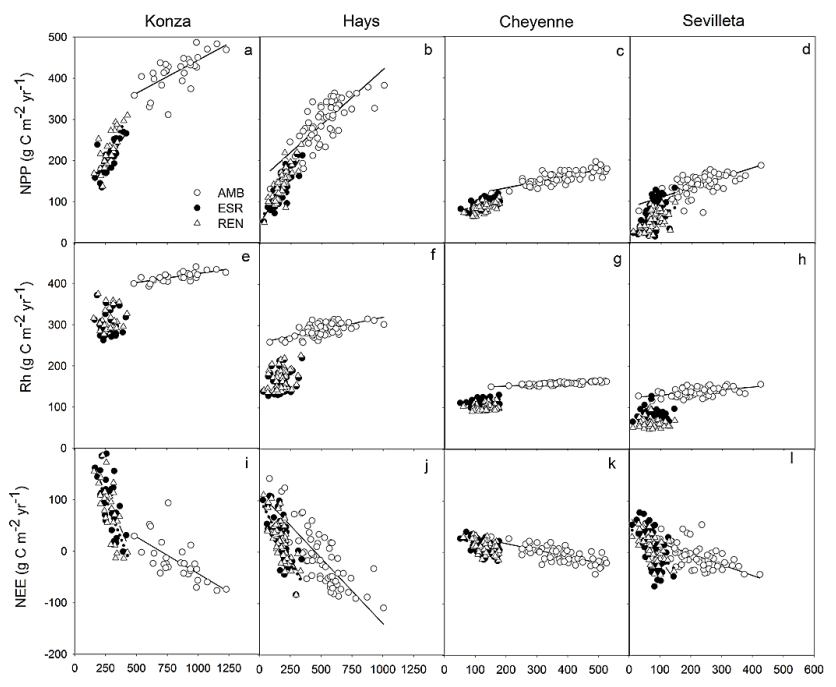

Annual rainfall $(\mathrm{mm})$

Fig. 4. Relationships between annual rainfall and annual $\mathrm{C}$ fluxes under the three rainfall scenarios (AMB: ambient rainfall; ESR: rainfall event size reduction; REN: reduced event number) in four North American grasslands (Konza: a, e and i; Hays: b, $\mathbf{f}$ and j; Cheyenne: $\mathbf{c}, \mathbf{g}$ and $\mathbf{k}$; Sevilleta: $\mathbf{d}, \mathbf{h}$ and $\mathbf{l})$. Annual rainfall determined grassland ecosystem carbon fluxes.

\subsection{Controls on annual $\mathrm{C}$ fluxes and the long-term impacts of drought}

Annual NPP increased with increasing rainfall amounts for all the grasslands under each of the three rainfall scenarios (ambient, ESR, and REN; Fig. 4a-d). The slopes of change in NPP were greater under the drought scenarios than that under ambient conditions (Table S3). Annual NEE decreased with rainfall (Fig. 4i-1). The slopes were negative and smaller under drought treatments than under ambient condition (Table S3). Annual $R_{\mathrm{h}}$ was not related to rainfall under drought scenarios, but a positive linear relationship with rainfall was noted under ambient conditions for all grasslands (Fig. 4eh). The interannual variation in the relative reduction in NPP negatively correlated with annual rainfall amount in all grassland sites except for Cheyenne (Fig. 5), and the relative reduction in $R_{\mathrm{h}}$ was positively correlated with drought-induced relative reductions in soil $\mathrm{C}$ content (Fig. 6).

Contribution from reduced soil $\mathrm{C}$ to the drought sensitivity of $R_{\mathrm{h}}$ increased over time, and contributions from both reduced NPP and soil water content decreased over time (Fig. 7). In general, reductions in NPP and soil water content contributed more than reduction in soil $\mathrm{C}$ in the early years, whereas their relative importance switched later on (Fig. 7) due to gradually increased reduction in soil $\mathrm{C}$ content.

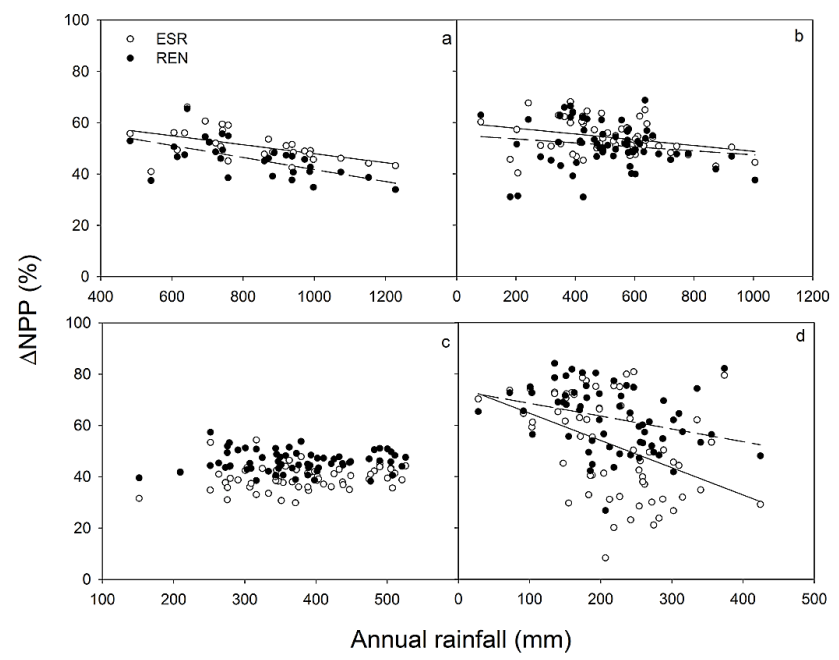

Fig. 5. Relationships between annual rainfall and drought-induced relative reduction in NPP in four North American grasslands (Konza: a; Hays: b; Cheyenne: c; Sevilleta: d). Open circles represent ESR treatment. Solid circles represent REN treatment. Variation in drought-induced relative reduction in NPP was significantly related to annual precipitation for all but the northern mixed grass site (Cheyenne).

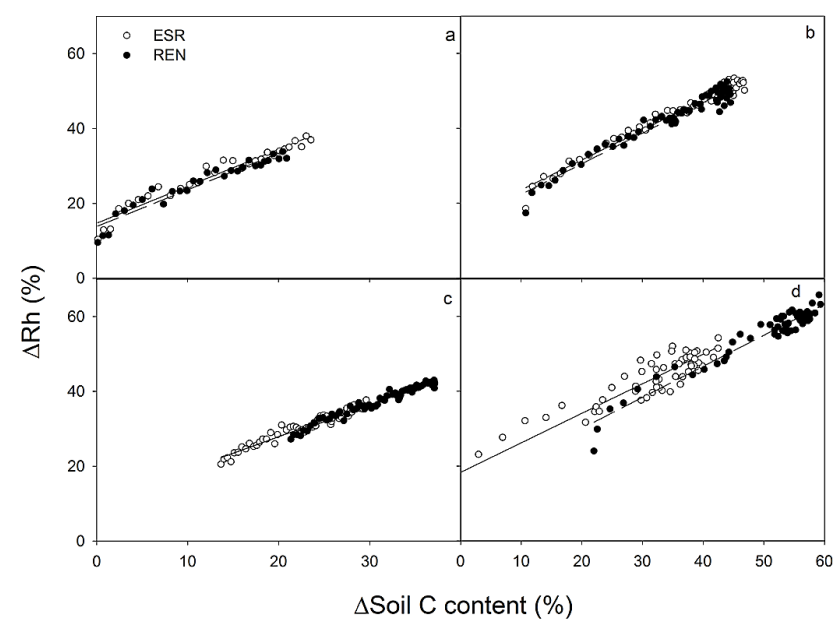

Fig. 6. Relationships between drought-induced relative reduction in soil C content and relative reduction in $R_{\mathrm{h}}$ in four North American grasslands (Konza: a; Hays: b; Cheyenne: c; Sevilleta: d). Open circles represent ESR treatment. Solid circles represent REN treatment. Drought-induced reductions in soil $\mathrm{C}$ were significantly and positively related to $R_{\mathrm{h}}$ reduction.

\section{Discussion}

Our synthesis and modeling analysis both revealed that production (GPP and NPP) was more sensitive to moderate to severe drought than respiration was (ER and $R_{\mathrm{h}}$ ). Furthermore, this differential sensitivity between production and respiration increased as drought severity increased; it occurred only 


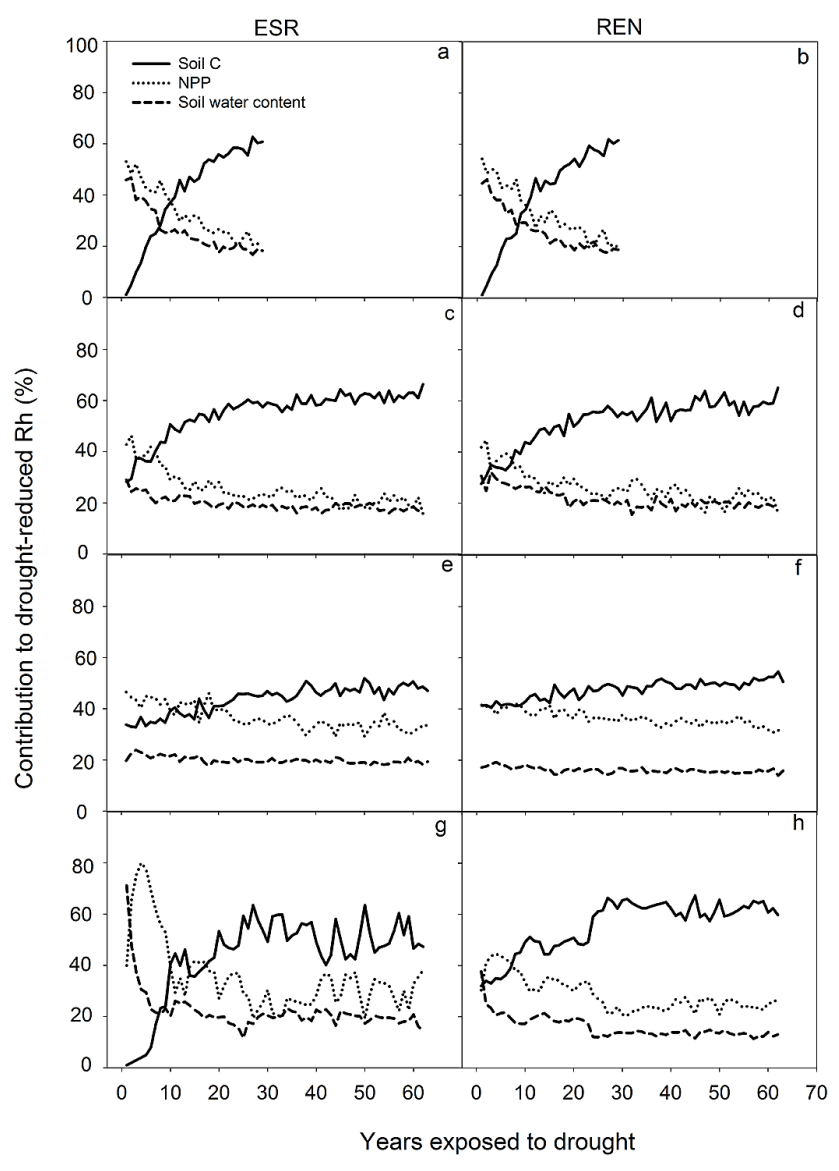

Fig. 7. Relative contributions to drought sensitivity of $R_{\mathrm{h}}$ from reductions in soil C content, NPP and soil water content under both rainfall reduction treatments in four North American grasslands (Konza: $\mathbf{a}$ and b; Hays: $\mathbf{c}$ and d; Cheyenne: e and f; Sevilleta: $\mathbf{g}$ and $\mathbf{h}$ ). Solid lines represent contribution due to reduction in soil $\mathrm{C}$, dotted lines represent contribution due to reduction in NPP, and dashed lines represent contribution due to reduction in soil water content.

in grassland ecosystems, and not in evergreen needle-leaf and broad-leaf forests or woody savannahs. In the modeling analysis, NPP was reduced more than $R_{\mathrm{h}}$ by extreme drought. However, the difference between NPP and $R_{\mathrm{h}}$ (i.e., NEE) diminished over time (multiple years) with drought. Our findings suggest that responses of production and respiration to drought differ in magnitude, occur on different timescales, and are affected by different mechanisms under extreme, prolonged drought. Additionally, the finding of different responses to drought types indicates the diverse interactive effects on ecosystem functions between rainfall variability and rainfall amount.

\subsection{General patterns of drought effects on production and respiration}

In the literature synthesis, GPP and ER responded differently to extreme and moderate drought, but not to minor drought, which suggests that moderate to extreme drought may override other confounding factors, for example site characteristics, climate conditions, and dominant plant species. However, during minor drought, evidence indicates that the responses of GPP and ER were largely regulated by topographic position and soil texture (Kljun et al., 2006), droughtassociated high summer radiation (Granier et al., 2007) and high summer temperature (Welp et al., 2007), along with a lagged effect from previous soil water condition (Welp et al., 2007). A broad range of ecosystems were included in the synthesis (Table S1), for example, grasslands, deciduous broad-leaf forests, evergreen needle-leaf forests, woody savanna, and shrubland. Thus, the general pattern of such differential responses is representative and robust across biomes. When synthesized data were analyzed based on ecosystem types, differential responses of production and respiration were not found in forest ecosystems. There are two possibly main reasons. The rooting systems of forests could partially relieve drought stress on production by tapping deep soil water (Kerhoulas et al., 2013) and secondly, most of the forest ecosystems only experienced moderate or minor drought in the synthesized studies. On the other hand, most of the grassland ecosystems went through extreme drought and do not have deep rooting systems, together resulting in the differential responses.

In contrast to the general pattern, however, in rainforest ecosystems where dry seasons occur annually, seasonal drought had limited effects on GPP due to adequate water supply from deep soil layers and hydraulic redistribution by deep roots. Therefore, rainforest GPP is generally controlled more by factors such as solar radiation (Bonal et al., 2008) than it is by precipitation. Indeed, previous modeling studies that included deep water supply and hydraulic redistribution closely captured the seasonal drought effects in rainforest (Baker et al., 2008). Even though trees in other ecosystems were also able to tap deep soil water (e.g., Kerhoulas et al., 2013), GPP was still reduced due to drought-increased vapor pressure deficit, which causes leaf stomata to partially close (Kolb et al., 2013).

\subsection{Mechanisms underlying differential response of production and respiration to drought}

In agreement with the synthesis results, the modeling analysis revealed the general pattern that production (GPP and NPP) was more drought-sensitive than respiration (ER and $R_{\mathrm{h}}$ ). The underlying mechanisms were explored in the model analysis of four grasslands over a rainfall gradient ranging from 240 to $860 \mathrm{~mm}$. The greater sensitivity of modeled NPP to extreme drought, which we observed (Fig. 3) at all four 
sites, was due to different controls of the two ecosystem C variables. In grassland ecosystems, production generally increases linearly or asymptotically with rainfall amount (e.g., Fig. 4; Sala et al., 1988; Huxman et al., 2004). Therefore, in the extreme drought treatments, NPP declined almost linearly with precipitation amount. However, heterotrophic respiration, which is the mineralization of litter and soil $\mathrm{C}$, is a $\mathrm{C}$ pool-controlled ecological process that is often regulated by soil temperature over the long term, in addition to soil water content and substrate availability in the short term (Luo and Zhou, 2006; Vargas et al., 2010). Therefore, drought-induced reductions in NPP, soil water content, and soil C content all contributed to the reduction in $R_{\mathrm{h}}$. Responses of NPP and soil water content were prompt and contributed significantly to reduced $R_{\mathrm{h}}$ in the early years, especially in the most mesic site. However, their contributions generally decreased over time due to the increased relative importance of reduction in soil C content. As a consequence, $R_{\mathrm{h}}$ was less impacted than NPP in the short term, and the difference gradually disappeared over time. Even though reduction in soil C content is relative smaller to short-term drought than NPP and soil water content, its smaller reduction played a more important role than NPP and soil water content due to its high correlation with $R_{\mathrm{h}}$, especially in the arid sites.

The model analysis also showed that the reduction in $R_{\mathrm{h}}$ increased during long-term drought due to diminishment of soil $\mathrm{C}$ pool size. The decrease in the soil $\mathrm{C}$ pool could be caused by drought-reduced NPP, the primary source of soil C. We are not aware of any empirical studies that reported long-term effects of drought on soil $\mathrm{C}$ and $R_{\mathrm{h}}$. However, space-for-time studies provide indirect evidence regarding ecosystem $\mathrm{C}$ dynamics under long-term climatic changes (Luo et al., 2011). For example, soil C declined linearly with decreasing precipitation in observations along precipitation gradients (Anderson et al., 2011; Talmon et al., 2011), which indirectly supports model results indicating a longterm drought-induced decrease in soil $\mathrm{C}$ content. This longterm decline in soil $\mathrm{C}$ content could cause the difference between the drought sensitivities of production and respiration to diminish gradually over time. Due to these differential responses over longer timescales, our modeling results showed that grassland ecosystems all released $\mathrm{CO}_{2}$ to the atmosphere during drought, but that the amount of released $\mathrm{CO}_{2}$ decreased over time as soil $\mathrm{C}$ pools declined. The model results, however, would benefit from long-term field experiments carried out to direct support for these results. This exploration of ecosystem sensitivity dynamics over the long term is critical for global change studies because many ecological responses are strongly regulated by slow processes (Luo et al., 2011).

Our model results also showed that Sevilleta and Cheyenne had the largest and least interannual variation, respectively, in the relative reduction of NPP and $R_{\mathrm{h}}$. Soil texture has long been known to affect plant productivity through the inverse soil texture effect (Noy-Meir, 1973) and has the potential to interact with rainfall regimes and mediate the impacts of drought (Weng and Luo, 2008). The much larger interannual variability in the relative reduction in NPP and $R_{\mathrm{h}}$ in Sevilleta could be explained by coarse-textured soils, because lower average water availability can amplify drought effects (Paruelo et al., 1999). The low variability and lack of correlation between rainfall and relative reduction in NPP at Cheyenne may have occurred because the lower average temperatures for this site relative to the other three (Table 1) resulted in less evaporation, and thus increased available water for plants and constrained the interannual variation in sensitivity to drought. These results emphasize the need for multisite long-term drought experiments, because interannual variation in precipitation as well as lagged effects from soil water storage likely play important roles in regulating ecosystem responses to climate extremes (Granier et al., 2007).

The mechanisms associated with drought responses in forest ecosystems are likely to be similar to those in grasslands. The primary responses of forests to drought are to reduce productivity and respiration due to water deficit (Dale et al., 2001) and the responses of production and respiration could be different. However, it is also likely that the mechanisms could be more complicated in forest ecosystems than in grasslands, and consequently have different long-term effects. For example, deep rooting systems in forest ecosystems could buffer the drought effect on production in forest ecosystems; drought associated increase in solar radiation might increase production as we found in rainforest; hydraulic lifting by tree roots could also alleviate the drought effect on C processes. As we found out in our synthesis, drought had similar effects on both production and respiration in forest ecosystems (Fig. 2b). As a consequence, the long-term response pattern may be different from that in the grassland ecosystems. Therefore, it is critical to include the possible mechanisms described above when simulating a long-term drought effect in a forest ecosystem.

\subsection{Drought attributes and differential responses of production and respiration}

In our modeling analyses, total annual rainfall in the two reduced-rainfall treatments was the same. Drought imposed by reducing every event (ESR treatment) was characterized by lower rainfall event size (one-third of ambient rainfall), but also by ambient rainfall frequency. By comparison, the REN treatment was characterized by ambient rainfall event size but lower frequency, and longer dry intervals between rain events. Responses of NPP and $R_{\mathrm{h}}$ to these treatments were contingent on grassland type, with greater reductions in NPP and $R_{\mathrm{h}}$ when drought was caused by every rain event becoming smaller (ESR scenario) at the two most mesic and productive grasslands (Konza and Hays). However, REN also caused a reduction in both NPP and $R_{\mathrm{h}}$. Knapp et al. (2002) also observed that lower frequency in rainfall events without 
changing total rainfall in a mesic tallgrass prairie resulted in less production than ambient rainfall frequency. However, if annual precipitation amount was low (1/3 of ambient rainfall in our study), the larger rainfall event size under REN relative to ESR could lead to higher soil water content and consequently higher production (Fig. S1a and b) in mesic grasslands. More water was stored in deep soil layers under ambient rainfall event size compared to lower rainfall event size in ESR, which decreased evaporative loss to the atmosphere and increased water availability to plants. Lower rainfall frequency (i.e., REN treatment), however, led to lower NPP in xeric grasslands (Fig. S1c and d). Frequent small rainfall events (the ESR treatment) can potentially alleviate chronic water stress, whereas the longer dry period under REN could affect early leaf and root growth due to being constantly under the threshold of a certain soil water content level. The underdeveloped leaves and roots can have a legacy effect on photosynthesis and water uptake later on and therefore decrease production more. In addition, different levels of rainfall frequency could affect its effect size (Heisler-White et al., 2009). Responses of $R_{\mathrm{h}}$ to the two drought types are consistent with those of NPP, indicating that NPP controls the responses of $R_{\mathrm{h}}$ to different drought types.

\subsection{Implications for future experimental studies}

Our findings have several important implications for field experiments. First, reported observations and manipulative climate change studies are often short-term. The snapshot of observed responses, therefore, may not be representative of long-term responses, especially when slow ecological processes are involved. Second, many manipulated drought experiments only decrease event sizes. Our results showed that reduced rainfall event number had differential effects on ecological processes rather than simply decreasing the size of each rain event. Future experiments should impose drought through different patterns of rainfall size, and different levels of frequency and intensity. Third, other components of ecosystem $\mathrm{C}$ processes should be assessed in global change experiments in addition to production. Different ecosystem $\mathrm{C}$ variables are likely to have different response patterns to imposed perturbation. In order to provide information on the positive or negative feedbacks of terrestrial biomes to climate change, measurements of both production and respiration are needed.

\subsection{Model limitations}

Ecosystem carbon models have often been used as a tool to investigate the effects of global changing on ecosystem carbon cycling (Norby and Luo, 2004; Parton et al., 2007; Luo et al., 2008; Schwalm et al., 2010b; Grant et al., 2011). At present, most of the models, however, do not represent photosynthetic and respiratory acclimation (Smith and Dukes, 2013), mortality (McDowell et al., 2013), and species shift
(Sebastia et al., 2008) well yet, due to our limited understanding of these processes. As a consequence, the regulation of these processes may not be well captured in the modeling results when models are used to simulate long-term effects of climate-changing factors on ecosystems. In this study, we used data from space-for-time studies to support our model results. For example, soil $\mathrm{C}$ declined linearly with decreasing precipitation in observations along precipitation gradients (Anderson et al., 2011; Talmon et al., 2011); this is consistent with our modeling results, which indicate a long-term drought-induced decrease in soil C content. This consistency between model and empirical studies suggest that the responses of ecosystem variables to extreme climatic changes are unlikely to be overridden by biotic adaptation (Anderson et al., 2011). Rather, the extent of the responses might be attenuated or exacerbated (Smith, 2011; Reichstein et al., 2013). Nonetheless, further research is needed to incorporate acclimation, adaptation and vegetation change into ecosystem models to improve ecological forecasting.

Vegetation mortality due to carbon starvation, hydraulic failure or both (McDowell et al., 2008) is likely to occur if the drought is severe enough and can therefore have a legacy effect on most aspects of ecosystem carbon cycling (Liu et al., 2011). It is difficult for ecosystem models to accurately capture plant mortality, due to the lack of thorough understanding of its mechanisms (Xu et al., 2013; McDowell et al., 2013; Reichstein et al., 2013). Mortality in grasslands differs from that in forest ecosystems. In a forest ecosystem, when large area of mortality occurs, the whole ecosystem would have to start over from secondary succession. However, grasslands are characterized by the high recovery potential of plant growth; they would recover to their original states in a very short time and have less impact on carbon cycling than forest ecosystems (Reichstein et al., 2013).

Another limitation in our study is possible model bias due to the fact that only one ecosystem model was used. A multiple-model intercomparison (MI) would be helpful in testing the robustness of our main conclusion that extreme drought had differential effect on production and respiration in grassland ecosystems. However, this is not our focus of this study. Nonetheless, findings from previous multiple model analysis can provide evidence for the robustness of our conclusion. For example, using four ecosystem C models, Luo et al. (2008) explored potential individual and interactive effects of climate warming, altered precipitation amount, and elevated $\mathrm{CO}_{2}$ concentration across a broad range of biomes. They found that a decrease of precipitation by half reduced net primary production more than heterotrophic respiration, and as a result decreased net ecosystem production.

\section{Supplementary material related to this article is

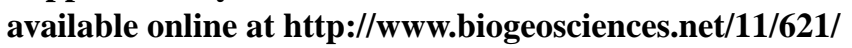 2014/bg-11-621-2014-supplement.pdf.}


Acknowledgements. The authors thank Ensheng Weng for valuable suggestions and Jianyang Xia for help with statistical analysis. This study was financially supported by NSF Macrosystems Biology grant EF 1137293 and grants to Kansas State University and the University of New Mexico for long-term ecological research.

Edited by: C. Williams

\section{References}

Anderson-Teixeira, K. J., Delong, J. P., Fox, A. M., Brese, D. A., and Litvak, M. E.:, Differential responses of production and respiration to temperature and moisture drive the carbon balance across a climatic gradient in New Mexico, Glob. Change Biol., 17, 410-424, doi:10.1111/j.1365-2486.2010.02269.x, 2011.

Arora, V. K. and Boer, G. J.: A parameterization of leaf phenology for the terrestrial ecosystem component of climate models, Glob. Change Biol., 11, 39-59, 2005.

Báez, S., Collins, S. L. Pockman, W. T., Johnson, J. E., and Small, E. E.: Effects of experimental rainfall manipulations on Chihuahuan Desert grassland and shrubland plant communities, Oecologia, 172, 1117-1127, 2013.

Baker, I. T., Prihodko, L., Denning, A. S., Goulden, M., Miller, S., and da Rocha, H. R.: Seasonal drought stress in the Amazon: Reconciling models and observations, J. Geophys. Res.-Biogeo., 113, G00B01, doi:10.1029/2007jg000644, 2008.

Ball, J. T., Woodrow, I. E., and Berry, J. A.: A model predicting stomatal conductance and its contribution to the control of photosynthesis under different environmental conditions, in: Progress in Photosynthesis Research, edited by Biggens, J., 221-224, Martinus Nijhoff, Zoetermeer, Netherlands, 1987.

Bonal, D., Bosc, A., Ponton, S., Goret, J. Y., Burban, B., Gross, P., Bonnefond, J. M., Elbers, J., Longdoz, B., Epron, D., Guehl, J. M., and Granier, A.: Impact of severe dry season on net ecosystem exchange in the Neotropical rainforest of French Guiana, Glob. Change Biol., 14, 1917-1933, doi:10.1111/j.13652486.2008.01610.x, 2008.

Bréda, N., Huc, R., Granier, A., and Dreyer, E.: Temperate forest trees and stands under severe drought: a review of ecophysiological responses, adaptation processes and long-term consequences, Ann. For. Sci., 63, 625-644, 2006.

Carrillo, Y., Pendall, E., Dijkstra, F. A., Morgan, J. A., and Newcomb, J. M.: Response of soil organic matter pools to elevated $\mathrm{CO}_{2}$ and warming in a semi-arid grassland, Plant Soil, 347, 339350, doi:10.1007/s11104-011-0853-4, 2011.

Cherwin, K. and Knapp, A.: Unexpected patterns of sensitivity to drought in three semi-arid grasslands, Oecologia, 169, 845-852, 2012.

Chimner, R. A., Welker, J. M., Morgan, J., LeCain, D., and Reeder, J.: Experimental manipulations of winter snow and summer rain influence ecosystem carbon cycling in a mixedgrass prairie, Wyoming, USA, Ecohydrology, 3, 284-293, doi:10.1002/Eco.106, 2010.

Ciais, P., Reichstein, M., Viovy, N., Granier, A., Ogée, J., Allard, V., Aubinet, M., Buchmann, N., Bernhofer, C., Carrara, A., Chevallier, F., De Noblet, N., Friend, A. D., Friedlingstein, P., Grünwald, T., Heinesch, B., Keronen, P., Knohl, A., Krinner, G., Loustau, D., Manca, G., Matteucci, G., Miglietta, F., Ourcival, J. M., Papale, D., Pilegaard, K., Rambal, S., Seufert, G., Soussana, J. F.,
Sanz, M. J., Schulze, E. D., Vesala, T., and Valentini, R.: Europewide reduction in primary productivity caused by the heat and drought in 2003, Nature, 437, 529-533, 2005.

Dai, A. G.: Drought under global warming: a review, Wires Clim. Change, 2, 45-65, doi:10.1002/Wcc.81, 2011.

Dale, V. H., Joyce, L. A., McNulty, S., Neilson, R. P., Ayres, M. P., Flannigan, M. D., Hanson, P. J., Irland, L. C., Lugo, A. E., Peterson, C. J., Simberloff, D., Swanson, F. J., Stocks, B. J., and Wotton, B. M.: Climate change and forest disturbances, Bioscience, 51, 723-734, doi:10.1641/00063568(2001)051[0723:Ccafd]2.0.Co;2, 2001.

Denison, F. and Loomis, B.: An integrative physiological model of alfalfa growth and development, UC ANR Publication 1926, Univ. California, Davis, 1989.

Farquhar, G. D., von Caemmerer, S., and Berry, J. A.: A biochemical model of photosynthetic $\mathrm{CO}_{2}$ assimilation in leaves of $\mathrm{C} 3$ species, Planta, 149, 78-90, 1980.

Goulden, M. L., Miller, S. D., da Rocha, H. R., Menton, M. C., de Freitas, H. C., Figueira, A. M. E. S., and de Sousa, C. A. D.: Diel and seasonal patterns of tropical forest $\mathrm{CO}_{2}$ exchange, Ecol. Appl., 14, S42-S54, 2004.

Granier, A., Reichstein, M., Breda, N., Janssens, I. A., Falge, E., Ciais, P., Grunwald, T., Aubinet, M., Berbigier, P., Bernhofer, C., Buchmann, N., Facini, O., Grassi, G., Heinesch, B., Ilvesniemi, H., Keronen, P., Knohl, A., Kostner, B., Lagergren, F., Lindroth, A., Longdoz, B., Loustau, D., Mateus, J., Montagnani, L., Nys, C., Moors, E., Papale, D., Peiffer, M., Pilegaard, K., Pita, G., Pumpanen, J., Rambal, S., Rebmann, C., Rodrigues, A., Seufert, G., Tenhunen, J., Vesala, I., and Wang, Q.: Evidence for soil water control on carbon and water dynamics in European forests during the extremely dry year: 2003, Agr Forest Meteorol, 143, 123-145, doi:10.1016/j.agrformet.2006.12.004, 2007.

Grant, R. F., Humphreys, E. R., Lafleur, P. M., and Dimitrov, D. D.: Ecological controls on net ecosystem productivity of a mesic arctic tundra under current and future climates, J. Geophys. Res.Biogeo., 116, G01031, doi:10.1029/2010jg001555, 2011.

Harper, C. W., Blair, J. M., Fay, P. A., Knapp, A. K., and Carlisle, J. D.: Increased rainfall variability and reduced rainfall amount decreases soil $\mathrm{CO}_{2}$ flux in a grassland ecosystem, Glob. Change Biol., 11, 322-334, 2005.

Heisler-White, J. L., Blair, J. M., Kelly, E. F., Harmoney, K., and Knapp, A. K.: Contingent productivity responses to more extreme rainfall regimes across a grassland biome, Global Change Biol., 15, 2894-2904, doi:10.1111/j.1365-2486.2009.01961.x, 2009.

Hutyra, L. R., Munger, J. W., Saleska, S. R., Gottlieb, E., Daube, B. C., Dunn, A. L., Amaral, D. F., de Camargo, P. B., and Wofsy, S. C.: Seasonal controls on the exchange of carbon and water in an Amazonian rain forest, J. Geophys. Res.-Biogeo., 112, G03008, doi:10.1029/2006jg000365, 2007.

Huxman, T. E., Smith, M. D., Fay, P. A., Knapp, A. K., Shaw, M. R., Loik, M. E., Smith, S. D., Tissue, D. T., Zak, J. C., Weltzin, J. F., Pockman, W. T., Sala, O. E., Haddad, B. M., Harte, J., Koch, G. W., Schwinning, S., Small, E. E., and Williams, D. G.: Convergence across biomes to a common rain-use efficiency, Nature, 429, 651-654, doi:10.1038/Nature02561, 2004.

IPCC: Intergovernmental Panel on Climate Change 2007, Climate change 2007: The physical science basis, Summary for policymakers, New York Cambridge University Press, 2007. 
Jentsch, A., Kreyling, J., Elmer, M., Gellesch, E., Glaser, B., Grant, K., Hein, R., Lara, M., Mirzae, H., Nadler, S. E., Nagy, L., Otieno, D., Pritsch, K., Rascher, U., Schädler, M., Schloter, M., Singh, B. K., Stadler, J., Walter, J., Wellstein, C., Wöllecke, J., and Beierkuhnlein, C.: Climate extremes initiate ecosystemregulating functions while maintaining productivity, J. Ecol., 99, 689-702, doi:10.1111/j.1365-2745.2011.01817.x, 2011.

Johnson, D., Vachon, J., Britton, A. J., and Helliwell, R. C.: Drought alters carbon fluxes in alpine snowbed ecosystems through contrasting impacts on graminoids and forbs, New Phytol., 190, 740-749, doi:10.1111/j.1469-8137.2010.03613.x, 2011.

Jongen, M., Pereira, J. S., Aires, L. M. I., and Pio, C. A.: The effects of drought and timing of precipitation on the inter-annual variation in ecosystem-atmosphere exchange in a Mediterranean grassland, Agr. Forest Meteorol., 151, 595-606, doi:10.1016/j.agrformet.2011.01.008, 2011.

Kerhoulas, L. P., Kolb, T. E., and Koch, G. W.: Tree size, stand density, and the source of water used across seasons by ponderosa pine in northern Arizona, Forest Ecol. Manag., 289, 425-433, doi:10.1016/j.foreco.2012.10.036, 2013.

Kljun, N., Black, T. A., Griffis, T. J., Barr, A. G., Gaumont-Guay, D., Morgenstern, K., McCaughey, J. H., and Nesic, Z.: Response of net ecosystem productivity of three boreal forest stands to drought, Ecosystems, 9, 1128-1144, doi:10.1007/s10021-0050082-x, 2006

Knapp, A. K., Fay, P. A., Blair, J. M., Collins, S. L., Smith, M. D., Carlisle, J. D., Harper, C. W., Danner, B. T., Lett, M. S., and McCarron, J. K.: Rainfall variability, carbon cycling, and plant species diversity in a mesic grassland, Science, 298, 2202-2205, doi:10.1126/science.1076347, 2002.

Knapp, A. K., Burns, C. E., Fynn, R. W., Kirkman, K. P., Morris, C. D., and Smith, M. D.: Convergence and contingency in production-precipitation relationships in North American and South African C 4 grasslands, Oecologia, 149, 456-464, 2006.

Kolb, T., Dore, S., and Montes-Helu, M.: Extreme late-summer drought causes neutral annual carbon balance in southwestern ponderosa pine forests and grasslands, Environ. Res. Lett., 8, 015015, doi:10.1088/1748-9326/8/1/015015, 2013.

Kosugi, Y., Tanaka, H., Takanashi, S., Matsuo, N., Ohte, N., Shibata, S., and Tani, M.: Three years of carbon and energy fluxes from Japanese evergreen broad-leaved forest, Agr. Forest Meteorol., 132, 329-343, doi:10.1016/j.agrformet.2005.08.010, 2005.

Liu, S. G., Bond-Lamberty, B., Hicke, J. A., Vargas, R., Zhao, S. Q., Chen, J., Edburg, S. L., Hu, Y. M., Liu, J. X., McGuire, A. D., Xiao, J. F., Keane, R., Yuan, W. P., Tang, J. W., Luo, Y. Q., Potter, C., and Oeding, J.: Simulating the impacts of disturbances on forest carbon cycling in North America: Processes, data, models, and challenges, J. Geophys. Res.-Biogeosci., 116, G00K08, doi:10.1029/2010jg001585, 2011.

Luo, Y. and Reynolds, J. F.: Validity of extrapolating field $\mathrm{CO}_{2}$ experiments to predict carbon sequestration in natural ecosystems, Ecology, 80, 1568-1583, 1999.

Luo, Y. and Zhou, X.: Soil respiration and the environment, Academic press, 2006.

Luo, Y. Q. and Weng, E. S.: Dynamic disequilibrium of the terrestrial carbon cycle under global change, Trends Ecol. Evol., 26, 96-104, doi:10.1016/j.tree.2010.11.003, 2011.

Luo, Y., Gerten, D., Le Maire, G., Parton, W. J., Weng, E., Zhou, X., Keough, C., Beier, C., Ciais, P., Cramer, W., Dukes, J. S.,
Emmett, B., Hanson, P. J., Knapp, A., Linder, S., Nepstad, D., and Rustad, L.: Modeled interactive effects of precipitation, temperature, and $\left[\mathrm{CO}_{2}\right]$ on ecosystem carbon and water dynamics in different climatic zones, Glob. Change Biol., 14, 1986-1999, doi:10.1111/j.1365-2486.2008.01629.x, 2008.

Luo, Y., Melillo, J., Niu, S., Beier, C., Clark, J. S., Classen, A. T., Davidson, E., Dukes, J. S., Evans, R. D., Field, C. B., Czimczik, C. I., Keller, M., Kimball, B. A., Kueppers, L. M., Norby, R. J., Pelini, S. L., Pendall, E., Rastetter, E., Six, J., Smith, M., Tjoelker, M. G., and Torn, M. S.: Coordinated approaches to quantify long-term ecosystem dynamics in response to global change, Glob. Change Biol., 17, 843-854, doi:10.1111/j.13652486.2010.02265.x, 2011.

McDowell, N., Pockman, W. T., Allen, C. D., Breshears, D. D., Cobb, N., Kolb, T., Plaut, J., Sperry, J., West, A., Williams, D. G., and Yepez, E. A.: Mechanisms of plant survival and mortality during drought: why do some plants survive while others succumb to drought?, New Phytol., 178, 719-739, doi:10.1111/j.1469-8137.2008.02436.x, 2008.

McDowell, N. G., Fisher, R. A., Xu, C., Domec, J. C., Hölttä, T., Mackay, D. S., Sperry, J. S., Boutz, A., Dickman, L., Gehres, N., Limousin, J. M., Macalady, A., Martínez-Vilalta, J., Mencuccini, M., Plaut, J. A., Ogée, J., Pangle, R. E., Rasse, D. P., Ryan, M. G., Sevanto, S., Waring, R. H., Williams, A. P., Yepez, E. A., and Pockman, W. T.: Evaluating theories of drought-induced vegetation mortality using a multimodel-experiment framework, New Phytol., 200, 304-321, doi:10.1111/nph.12465, 2013.

Misson, L., Rocheteau, A., Rambal, S., Ourcival, J. M., Limousin, J. M., and Rodriguez, R.: Functional changes in the control of carbon fluxes after 3 years of increased drought in a Mediterranean evergreen forest?, Glob. Change Biol.,16, 2461-2475, doi:10.1111/j.1365-2486.2009.02121.x, 2010.

Muldavin, E. H., Moore, D. I., Collins, S. L., Wetherill, K. R., and Lightfoot, D. C.: Aboveground net primary production dynamics in a northern Chihuahuan Desert ecosystem, Oecologia, 155, 123-132, doi:10.1007/s00442-007-0880-2, 2008.

Nagy, Z., Pinter, K., Czobel, S., Balogh, J., Horvath, L., Foti, S., Barcza, Z., Weidinger, T., Csintalan, Z., Dinh, N. Q., Grosz, B., and Tuba, Z.: The carbon budget of semi-arid grassland in a wet and a dry year in Hungary, Agr Ecosyst Environ, 121, 21-29, doi:10.1016/j.agee.2006.12.003, 2007.

Noormets, A., McNulty, S. G., DeForest, J. L., Sun, G., Li, Q., and Chen, J.: Drought during canopy development has lasting effect on annual carbon balance in a deciduous temperate forest, New Phytol., 179, 818-828, doi:10.1111/j.1469-8137.2008.02501.x, 2008.

Norby, R. J. and Luo, Y. Q.: Evaluating ecosystem responses to rising atmospheric $\mathrm{CO}_{2}$ and global warming in a multifactor world, New Phytol., 162, 281-293, doi:10.1111/j.14698137.2004.01047.x, 2004.

Noy-Meir, I.: Desert ecosystems: Environment and producers, Annu. Rev. Ecol. Evol. S., 4, 25-51, 1973.

Parton, W. J., Morgan, J. A., Wang, G. M., and Del Grosso, S.: Projected ecosystem impact of the Prairie Heating and CO2 Enrichment experiment, New Phytol., 174, 823-834, doi:10.1111/j.1469-8137.2007.02052.x, 2007.

Paruelo, J. M., Lauenroth, W. K., Burke, I. C., and Sala, O. E.: Grassland precipitation-use efficiency varies across a resource 
gradient, Ecosystems, 2, 64-68, doi:10.1007/s100219900058, 1999.

Pereira, J. S., Mateus, J. A., Aires, L. M., Pita, G., Pio, C., David, J. S., Andrade, V., Banza, J., David, T. S., Paço, T. A., and Rodrigues, A.: Net ecosystem carbon exchange in three contrasting Mediterranean ecosystems - the effect of drought, Biogeosciences, 4, 791-802, doi:10.5194/bg-4-791-2007, 2007.

Potts, D. L., Suding, K. N., Winston, G. C., Rocha, A. V., and Goulden, M. L.: Ecological effects of experimental drought and prescribed fire in a southern California coastal grassland, J. Arid Environ., 81, 59-66, doi:10.1016/j.jaridenv.2012.01.007, 2012.

Reichstein, M., Tenhunen, J. D., Roupsard, O., Ourcival, J.-m., Rambal, S., Miglietta, F., Peressotti, A., Pecchiari, M., Tirone, G. and Valentini, R.: Severe drought effects on ecosystem $\mathrm{CO}_{2}$ and $\mathrm{H}_{2} \mathrm{O}$ fluxes at three Mediterranean evergreen sites: revision of current hypotheses?, Glob. Change Biol., 8, 999-1017, doi:10.1046/j.1365-2486.2002.00530.x, 2002.

Reichstein, M., Bahn, M., Ciais, P., Frank, D., Mahecha, M. D., Seneviratne, S. I., Zscheischler, J., Beer, C., Buchmann, N., Frank, D. C., Papale, D., Rammig, A., Smith, P., Thonicke, K., van der Velde, M., Vicca, S., Walz, A., and Wattenbach, M.: Climate extremes and the carbon cycle, Nature, 500, 287-295, doi:10.1038/Nature12350, 2013.

Sala, O. E., Parton, W. J., Joyce, L. A., and Lauenroth, W. K.: Primary production of the central grassland region of the UnitedStates, Ecology, 69, 40-45, doi:10.2307/1943158, 1988.

Saleska, S. R., Miller, S. D., Matross, D. M., Goulden, M. L., Wofsy, S. C., da Rocha, H. R., de Camargo, P. B., Crill, P., Daube, B. C., de Freitas, H. C., Hutyra, L., Keller, M., Kirchhoff, V., Menton, M., Munger, J. W., Pyle, E. H., Rice, A. H., and Silva, H.: Carbon in amazon forests: Unexpected seasonal fluxes and disturbance-induced losses, Science, 302, 1554-1557, doi:10.1126/science.1091165, 2003.

Sebastia, M. T., Kirwan, L., and Connolly, J.: Strong shifts in plant diversity and vegetation composition in grassland shortly after climatic change, J. Veg. Sci., 19, 299-306, doi:10.3170/2008-818356, 2008.

Schwalm, C. R., Williams, C. A., Schaefer, K., Arneth, A., Bonal, D., Buchmann, N., Chen, J., Law, B. E., Lindroth, A., Luyssaert, S., Reichstein, M., and Richardson, A. D.: Assimilation exceeds respiration sensitivity to drought: A FLUXNET synthesis, Glob. Change Biol., 16, 657-670, doi:10.1111/j.13652486.2009.01991.x, 2010a.

Schwalm, C. R., Williams, C. A., Schaefer, K., Anderson, R., Arain, M. A., Baker, I., Barr, A., Black, T. A., Chen, G. S., Chen, J. M., Ciais, P., Davis, K. J., Desai, A., Dietze, M., Dragoni, D., Fischer, M. L., Flanagan, L. B., Grant, R., Gu, L. H., Hollinger, D., Izaurralde, R. C., Kucharik, C., Lafleur, P., Law, B. E., Li, L. H., Li, Z. P., Liu, S. G., Lokupitiya, E., Luo, Y. Q., Ma, S. Y., Margolis, H., Matamala, R., McCaughey, H., Monson, R. K., Oechel, W. C., Peng, C. H., Poulter, B., Price, D. T., Riciutto, D. M., Riley, W., Sahoo, A. K., Sprintsin, M., Sun, J. F., Tian, H. Q., Tonitto, C., Verbeeck, H., and Verma, S. B.: A model-data intercomparison of $\mathrm{CO} 2$ exchange across North America: Results from the North American Carbon Program site synthesis, J. Geophys. Res.-Biogeo., 115, G00H05, doi:10.1029/2009jg001229, $2010 \mathrm{~b}$.

Schwalm, C. R., Williams, C. A., Schaefer, K., Baldocchi, D., Black, T. A., Goldstein, A. H., Law, B. E., Oechel, W. C., Paw U,
K. T., and Scott, R. L.: Reduction in carbon uptake during turn of the century drought in western North America, Nat. Geosci., 5, 551-556, 2012.

Scott, R. L., Hamerlynck, E. P., Jenerette, G. D., Moran, M. S., and Barron-Gafford, G. A.: Carbon dioxide exchange in a semidesert grassland through drought-induced vegetation change, J. Geophys. Res.-Biogeo., 115, G03026, doi:10.1029/2010jg001348, 2010.

Smith, N. G. and Dukes, J. S.: Plant respiration and photosynthesis in global-scale models: incorporating acclimation to temperature and $\mathrm{CO}_{2}$, Glob. Change Biol., 19, 45-63, doi:10.1111/j.13652486.2012.02797.x, 2013.

Smith, M. D.: An ecological perspective on extreme climatic events: a synthetic definition and framework to guide future research, J. Ecol., 99, 656-663, doi:10.1111/j.1365-2745.2011.01798.x, 2011.

Talmon, Y., Sternberg, M., and Grunzweig, J. M.: Impact of rainfall manipulations and biotic controls on soil respiration in Mediterranean and desert ecosystems along an aridity gradient, Glob. Change Biol., 17, 1108-1118, doi:10.1111/j.13652486.2010.02285.x, 2011.

Thomey, M. L., Collins, S. L., Vargas, R., Johnson, J. E., Brown, R. F., Natvig, D. O., and Friggens, M. T.: Effect of precipitation variability on net primary production and soil respiration in a Chihuahuan Desert grassland, Glob. Change Biol., 17, 15051515, doi:10.1111/j.1365-2486.2010.02363.x, 2011.

Vargas, R., Baldocchi, D. D., Allen, M. F., Bahn, M., Black, A., Collins, S. L., Yuste, J. C., Hirano, T., Jassal, R. S. Pumpanen, J., and Tang, J.: Looking deeper into the soil: environmental controls and seasonal lags of soil $\mathrm{CO}_{2}$ production and efflux across four vegetation types, Ecol. Appl., 20, 1569-1582, 2010.

Vargas, R., Collins, S. L., Thomey, M. L., Johnson, J. E., Brown, R. F., Natvig, D. O., and Friggens, M. T.: Precipitation variability and fire influence the temporal dynamics of soil $\mathrm{CO}_{2}$ efflux in an arid grassland, Glob. Change Biol., 18, 1401-1411, doi:10.1111/j.1365-2486.2011.02628.x, 2012.

Wang, Y. P. and Leuning R.: A two-leaf model for canopy conductance, photosynthesis and partitioning of available energy, part I: Model description and comparison with a multi-layered model, Agr. Forest Meteorol., 91, 89-111, 1998.

Welp, L. R., Randerson, J. T., and Liu, H. P.: The sensitivity of carbon fluxes to spring warming and summer drought depends on plant functional type in boreal forest ecosystems, Agr. Forest Meteorol., 147, 172-185, doi:10.1016/j.agrformet.2007.07.010, 2007.

Weng, E. and Luo Y.: Soil hydrological properties regulate grassland ecosystem responses to multifactor global change: A modeling analysis, J. Geophys. Res., 113, G03003, doi:10.1029/2007jg000539, 2008.

Wolf, S., Eugster, W., Potvin, C., Turner, B. L., and Buchmann, N.: Carbon sequestration potential of tropical pasture compared with afforestation in Panama, Glob. Change Biol., 17, 2763-2780, doi:10.1111/j.1365-2486.2011.02460.x, 2011.

Wu, Z. T., Koch, G. W., Dijkstra, P., Bowker, M. A., and Hungate, B. A.: Responses of ecosystem carbon cycling to climate change treatments along an elevation gradient, Ecosystems, 14, 10661080, doi:10.1007/s10021-011-9464-4, 2011. 
Xu, C., McDowell, N. G., Sevanto, S., and Fisher, R. A.: Our limited ability to predict vegetation dynamics under water stress, New Phytol., 200, 298-300, doi:10.1111/nph.12450, 2013.

Yahdjian L. and Sala O. E.: Vegetation structure constrains primary production response to water availability in the Patagonian steppe, Ecology, 87, 952-962, 2006.
Yang, F. L., and Zhou, G. S.: Sensitivity of temperate desert steppe carbon exchange to seasonal droughts and precipitation variations in Inner Mongolia, China, Plos One, 8, e55418, doi:10.1371/journal.pone.0055418, 2013.

Zhang, Y. P., Tan, Z. H., Song, Q. H., Yu, G. R., and Sun, X. M.: Respiration controls the unexpected seasonal pattern of carbon flux in an Asian tropical rain forest, Atmos. Environ., 44, 38863893, doi:10.1016/j.atmosenv.2010.07.027, 2010. 